\title{
Phenotypic and genetic relationships between indicators of the mammary gland health status and milk composition, coagulation, and curd firming in dairy sheep
}

\author{
Michele Pazzola, ${ }^{\star 1}$ Claudio Cipolat-Gotet, $† \ddagger$ Giovanni Bittante, $†$ Alessio Cecchinato, $†$ Maria L. Dettori, ${ }^{*}$ \\ and Giuseppe M. Vacca* \\ *Department of Veterinary Medicine, University of Sassari, via Vienna 2, 07100 Sassari, Italy \\ †Department of Agronomy, Food, Natural Resources, Animals and Environment (DAFNAE), University of Padova, viale dell'Università 16, \\ 35020 Legnaro (PD), Italy \\ ‡Department of Veterinary Science, University of Parma, Via del Taglio 10, 43126 Parma, Italy
}

\begin{abstract}
The present study investigated the effect of somatic cell count, lactose, and $\mathrm{pH}$ on sheep milk composition, coagulation properties (MCP), and curd firming $(\mathrm{CF})$ parameters. Individual milk samples were collected from 1,114 Sarda ewes reared in 23 farms. Milk composition, somatic cell count, single point MCP (rennet coagulation time, $\mathrm{RCT}$; curd firming time, $\mathrm{k}_{20}$; and curd firmness, $\mathrm{a}_{30}, \mathrm{a}_{45}$, and $\mathrm{a}_{60}$ ), and CF model parameters were achieved. Phenotypic traits were statistically analyzed using a mixed model to estimate the effects of the different levels of milk somatic cell score (SCS), lactose, and $\mathrm{pH}$, respectively. Additive genetic, herd, and residual correlations among these 3 traits, and with milk composition, MCP and CF parameters, were inferred using a Bayesian approach. From a phenotypic point of view, higher SCS levels caused a delayed gelification of milk. Lactose concentration and $\mathrm{pH}$ were significant for many milk quality traits, with a very intense effect on both coagulation times and curd firming. These traits (RCT, RCT estimated using the curd firming over time equation, and $\mathrm{k}_{20}$ ) showed an unfavorable increase of about $20 \%$ from the highest to the lowest level of lactose. Milk samples with $\mathrm{pH}$ values lower than 6.56 versus higher than 6.78 were characterized by an increase of RCT (from 6.00 to 14.3 min) and $\mathrm{k}_{20}$ (from 1.65 to $2.65 \mathrm{~min}$ ) and a decrease of all the 3 curd firmness traits. From a genetic point of view, the marginal posterior distribution of heritability estimates evidenced a large and exploitable variability for all 3 phenotypes. The mean intra-farm heritability
\end{abstract}

Received October 11, 2017.

Accepted December 15, 2017.

${ }^{1}$ Corresponding author: pazzola@uniss.it estimates were 0.173 for SCS, 0.418 for lactose content, and 0.206 for $\mathrm{pH}$. Lactose (favorably), and SCS and $\mathrm{pH}$ (unfavorably), at phenotypic and genetic levels, were correlated mainly with RCT and RCT estimated using the curd firming over time equation and scarcely with the other curd firming traits. The SCS, lactose, and $\mathrm{pH}$ were significantly correlated with each other's. In conclusion, results reported in the present study suggest that SCS, pH, and lactose affect, contemporarily and independently, milk quality and MCP. These phenotypes, easily available during milk recording schemes measured by infrared spectra prediction, could be used as potential indicators traits for improving cheesemaking ability of ovine milk.

Key words: sheep, milk coagulation, somatic cell count, lactose, $\mathrm{pH}$

\section{INTRODUCTION}

Although sheep milk production is limited compared with cow milk production, being $2 \%$ of total bovine milk yield (Ramos and Juarez, 2011), in many areas dairy ewes and their related production represent an important sector of agricultural activities. This occurrence is particularly evident for southern European countries, where small ruminants are traditionally linked to the territories and cultures (Boyazoglu and Morand-Fehr, 2001).

Given that sheep milk is almost completely processed into cheese, quality of raw milk is a fundamental feature to predict the final cheese yield. Composition and the measured coagulation properties are suitable at the laboratory and dairy industry level to assess the suitability of milk for cheese production (Bencini, 2002; Pazzola et al., 2014). Other aspects affecting milk quality are represented by hygienic traits. The negative influence of udder inflammatory condition on milk and cheese quality is a well-documented topic in dairy cows 
(Viguier et al., 2009) and sheep (Albenzio et al., 2004; Leitner et al., 2016).

Several markers for mastitis detection have been proposed both at the farm and dairy-plant level. Somatic cell count is the most used method (Hogeveen, 2011; Kelly et al., 2011). Somatic cells in milk are mainly represented by cells of the immune system and epithelial cells, and the difference between 2 or more consecutive counts are used to estimate inflammatory states and distinguish infected udders, as a positive correlation is present between udder inflammatory response and SCC (Schukken et al., 2003).

In the European Union, the criteria for hygienic production of sheep milk are reported in Regulation 853/2004 (EU, 2004), but no limit has been fixed for SCC. In the United States, sheep milk must meet standards set by the Ordinance of Pasteurized Milk of the Food and Drug Administration (US PMO, 2007), and content of somatic cells must be lower than $750,000 /$ $\mathrm{mL}$. Even with the differences between legal documents dealing with sheep milk SCC, the individual measurement of SCC is a useful tool to reveal subclinical mastitis also in dairy sheep farming (Berthelot et al., 2006; Boyazoglu and Morand-Fehr, 2001; Riggio and Portolano, 2015).

Many parameters other than SCC are proposed as diagnostic tools for mastitis (Hogeveen, 2011; Kelly et al., 2011; Jensen et al., 2016). In the past, lactose and $\mathrm{pH}$ changes have been used to estimate udder inflammatory processes (Vanlandingham et al., 1941). Mastitis causes damage to the barrier between blood and milk, the consequent change of fluid flow, and the interrelated variation of both lactose and $\mathrm{pH}$ (Poulsen et al., 2015). Recently, the decrease of lactose percentage has been regularly recognized for the detection of mastitis in cattle (Auldist et al., 1995; Gonçalves et al., 2016). Several studies have also estimated the genetic correlations between these milk traits and coagulation properties in both dairy cattle (Bittante et al., 2012) and sheep (Othmane et al., 2002; Puledda et al., 2017).

Up to date, no study has been conducted to simultaneously investigate, at the field level, the effect of milk quality markers on a complete range of ovine milk quality and technological traits. Therefore, the aims of the present study were (1) to investigate the effect of SCC, lactose, and $\mathrm{pH}$ on sheep milk composition, coagulation properties (MCP), and curd firming $(\mathbf{C F})$ parameters; (2) to assess the relevance of the aforementioned indicator traits of mammary gland status in explaining the variation of technological traits by estimating the additive genetic correlations between SCC, lactose, and $\mathrm{pH}$, and milk composition, MCP, and $\mathrm{CF}$ parameters.

\section{MATERIALS AND METHODS}

\section{Animals and Milk Sampling}

The present study is based on data recorded from 1,114 Sarda ewes reared in 23 different commercial farms located in Sardinia, Italy. Animals and farms are described in Pazzola et al. (2014). To obtain a representative sample of health animals, ewes were submitted to clinical examinations by veterinarians with experience in the field of small ruminant practice. Ewes showing clinical mastitis, and any other evident disease, were discarded, whereas healthy ewes were retained and sampled. This sampling strategy allowed to focus our study on associations between milk parameters and deviating levels of SCS, lactose, and $\mathrm{pH}$.

Sampled ewes ranged in number from 22 to 89 per each farm; they were between 2 and 7 mo after parturition, and from first to seventh parity.

Ewes from each farm were individually sampled on a single day. Milk samples were collected in 200-mL disposable sterile plastic containers during the afternoon milking and refrigerated at $4^{\circ} \mathrm{C}$. Daily milk yield (morning plus evening milking) was recorded on the same day of collection.

\section{Analysis of Milk Traits and Coagulation Properties}

Milk samples were analyzed within $24 \mathrm{~h}$ after collection for milk composition [fat, protein, casein, lactose, and $\mathrm{pH}$; casein number (\%) calculated as the ratio between casein and protein contents], SCC, and single point MCP (rennet coagulation time, RCT, as the interval between rennet addition and gel formation; curd firming time, $\mathbf{k}_{\mathbf{2 0}}$, as the interval between gel formation and a curd firmness of $20 \mathrm{~mm}$; and curd firmness $\mathbf{a}_{30}$, $\mathbf{a}_{45}$, and $\mathbf{a}_{60}, 30,45$, and 60 min after rennet addition, respectively). Lactose and $\mathrm{pH}$ were measured using a MilkoScan FT6000 milk analyzer (Foss Electric A/S); SCC with a Fossomatic 5000 somatic cell counter (Foss Electric A/S); the others traits were measured using the methods reported in Pazzola et al. (2014). The model parameters of curd-firming [curd firmness at an infinite time $\left(\mathbf{C}_{\mathbf{F P}}\right.$, measured in $\left.\mathbf{m m}\right)$, curd-firming instant rate constant $\left(\mathbf{k}_{\mathrm{CF}}, \% \times \mathrm{min}^{-1}\right)$, rennet coagulation time from the result of modeling $\left(\mathbf{R C T}_{\mathbf{e q}}, \mathrm{min}\right)$, syneresis instant rate constant $\left(\mathbf{k}_{\mathrm{SR}}, \% \times \mathrm{min}^{-1}\right)$ that tends to reduce curd firming over time $\left(\mathbf{C F}_{\mathrm{t}}\right)$ beyond a maximum curd firmness $\left(\mathbf{C F}_{\max }, \mathrm{mm}\right)$ after a given time interval $\left.\left(\mathbf{t}_{\max }, \min \right)\right]$ were measured as reported in Vacca et al. (2015). The analysis of both the traditional $\mathrm{MCP}$ and parameters of $\mathrm{CF}_{\mathrm{t}}$ modeling was performed 
to achieve a deeper description of milk coagulation traits: the former are more common and the latter are more informative of the complete pattern recorded by the lactodynamograph (Bittante et al., 2012; Vacca et al., 2015).

As regards MCP, RCT was labeled as missing for values higher than $30 \min (\mathrm{n}=5)$ and for not-coagulating samples ( $\mathrm{RCT}>60$ min, $\mathrm{n}=10) ; \mathrm{k}_{20}$ was labeled as missing for values higher than 5 min $(\mathrm{n}=19)$; values of curd firmness were missing at $0 \mathrm{~mm}\left(\mathrm{a}_{30}: \mathrm{n}=15\right.$; $\mathrm{a}_{45}: \mathrm{n}=10 ; \mathrm{a}_{60}: \mathrm{n}=7$ ). To normalize the distribution, SCC was transformed in the logarithmic score SCS $\left[\log _{2}\left(\mathrm{SCC} \times 10^{-5}\right)+3\right]$; Ali and Shook (1980).

\section{Statistical Analysis}

Phenotypic Analysis. Data were analyzed using the MIXED procedure of SAS (SAS Institute Inc., Cary, NC) according to the following linear model:

$$
\begin{gathered}
y_{i j k l m n o p q r}=\mu+\mathrm{DIM}_{i}+\text { parity }_{j}+\mathrm{MUCM}_{k}+\mathrm{dMY}_{l} \\
+ \text { flock } \text { size }_{m}+\text { farm }(\text { flock size })_{n m}+\mathrm{SCS}_{o} \\
+ \text { lactose }_{p}+\mathrm{pH}_{q}+e_{i j k l m n o p q r}
\end{gathered}
$$

where $y_{i j k l m n o p q r}$ is the observed trait; $\mu$ is the overall intercept of the model; $\mathrm{DIM}_{i}$ is the fixed effect of the $i$ th class of DIM ( $i=1$ to 8 ; class 1: 61 to $80 \mathrm{~d}$, class 2: 81 to $100 \mathrm{~d}$, class 3: 101 to $120 \mathrm{~d}$; class 4: 121 to $140 \mathrm{~d}$; class 5: 141 to $160 \mathrm{~d}$; class 6: 161 to $180 \mathrm{~d}$; class 7: 181 to $200 \mathrm{~d}$; class 8: $>200 \mathrm{~d}$ ); parity $_{j}$ is the fixed effect of the $j$ th parity of the ewes ( $j=1$ to 5 or more); $\mathrm{MUCM}_{k}$ is the fixed effect of the $k$ th measuring unit of the coagulation meter ( $k=1$ to 10$) ; \mathrm{dMY}_{l}$ is the fixed effect of $l$ th class of single test-day milk yield $(l=1$ to 7 : class $1<0.55$; class 2: 0.55 to 0.96 ; class 3 : 0.97 to 1.38 ; class 4: 1.39 to 1.79 ; class $5: 1.80$ to 2.21 ; class $6: 2.22$ to 2.64 ; class $7>2.64$ ); flock size ${ }_{m}$ is the fixed effect of $m$ th flock dimension ( $m=1$ to 3 ; class $1:<300$ ewes; class $2: 300$ to 600 ewes; class 3: $>600$ ewes); farm(flock size) ${ }_{n m}$ is the random effect of the farm/test day nested within flock size; $\mathrm{SCS}_{o}$ is the fixed effect of oth class of milk SCS $(o=1$ to 7 : class $1<2.07$; class 2 : 2.07 to 3.12 ; class 3: 3.13 to 4.18 ; class 4 : 4.19 to 5.25 ; class 5 : 5.26 to 6.31 ; class 6 : 6.32 to 7.37 ; class $7>7.37$ ); lactose $_{p}$ is the fixed effect of $p$ th class of milk lactose content $(p=$ 1 to 7 : class $1<4.47$; class 2: 4.47 to 4.61 ; class 3 : 4.62 to 4.75 ; class 4: 4.76 to 4.89 ; class 5: 4.90 to 5.03 ; class 6: 5.04 to 5.17; class $7>5.17) ; \mathrm{pH}_{q}$ is the fixed effect of $q$ th class of milk $\mathrm{pH}(q=1$ to 7 : class $1<6.56$; class 2 : 6.56 to 6.61 ; class 3 : 6.62 to 6.65 ; class 4 : 6.66 to 6.69 ; class 5: 6.70 to 6.73 ; class 6 : 6.74 to 6.78 ; class $7>6.78$ ) and $e_{i j k l m n o p q r}$ is the random residual. Each of the 7 classes of SCS, lactose, and $\mathrm{pH}$ were designed on the basis of distribution of the variables: each single class explained 0.5 standard deviation of the variable; the fourth was centered on the mean value; and the first and the seventh represented the tails of the distribution. The farm/test day nested within flock size and residuals were assumed to be independently and normally distributed with a mean of zero and variance $\sigma_{F}^{2}$ and $\sigma_{e}^{2}$. Percentage of variance explained by the farm was calculated by dividing the corresponding component of variance by the total variance.

Polynomial contrasts (linear, quadratic, and cubic component) were estimated to look at the effect of SCS, lactose, and $\mathrm{pH}$ on milk yield, quality, $\mathrm{MCP}$, and $\mathrm{CF}$.

Genetic Analysis. Nongenetic effects previously described were taken into account in estimating the genetic parameters between the 3 indicators of the mammary gland health status (i.e., SCC, lactose, and $\mathrm{pH}$ ) and milk composition, $\mathrm{MCP}$, and $\mathrm{CF}$ parameters. Briefly, the model accounted for the effects of farm-date (23 levels), DIM (8 levels), parity of the ewes (1 to 5 or more), and the measuring unit of the coagulation meter (MUCM; 10 levels, based on the position of the individual pendulum).

Bivariate sire models were fitted to estimate (co)variance components for the traits of concern. The model assumed was

$$
\mathbf{y}=\mathbf{X b}+\mathbf{Z}_{1} \mathbf{f}+\mathbf{Z}_{2} \mathbf{s}+\mathbf{e}
$$

where $\mathbf{y}$ is a vector of records for traits 1 and $2 ; \mathbf{X}, \mathbf{Z}_{1}$, and $\mathbf{Z}_{2}$ are appropriate incidence matrices for systematic effects in $\mathbf{b}$, farm/date effects in $\mathbf{f}$, and sire genetic effects in $\mathbf{s}$, respectively; and $\mathbf{e}$ is a vector of random residuals. (Co)variance components and related parameters were estimated using a Bayesian approach and Markov-chain Monte Carlo methods (Sorensen and Gianola, 2002). All traits were taken as continuous variables, and their values were assumed to be sampled from the following multivariate normal (MVN) distribution:

$$
p(\mathbf{y} \mid \mathbf{b}, \mathbf{f}, \mathbf{s}, \mathbf{R}) \sim M V N\left(\mathbf{X b}+\mathbf{Z}_{1} \mathbf{f}+\mathbf{Z}_{2} \mathbf{s}, \mathbf{I} \otimes \mathbf{R}\right),
$$

where $\mathbf{y}, \mathbf{b}, \mathbf{f}, \mathbf{s}, \mathbf{X}, \mathbf{Z}_{1}$, and $\mathbf{Z}_{2}$ are as defined above; $\mathbf{R}$ is a $2 \times 2$ matrix of residual (co)variances; and $\mathbf{I}$ is an identity matrix of appropriate order. The data were properly ordered within the vectors, and vectors $\mathbf{s}$ and $\mathbf{f}$ contained the effects of both traits individual by individual. 
In a Bayesian setting, we assumed

$$
p(\mathbf{s} \mid \mathbf{G}) \sim \operatorname{MVN}(0, \mathbf{A} \otimes \mathbf{G})
$$

and

$$
p(\mathbf{f} \mid \mathbf{F}) \sim M V N(0, \mathbf{I} \otimes \mathbf{F}),
$$

where $\mathbf{G}$ is a $2 \times 2$ sire (co)variance matrix, $\mathbf{A}$ is the additive genetic relationship matrix among sires, $\mathbf{F}$ is a $2 \times 2$ (co)variance matrix for farm/date effects, and $\mathbf{I}$ is the identity matrix of the same order as the number of levels of farm/date effects. Flat priors were assumed for the effects in $\mathbf{b}$, as well as for $\mathbf{G}, \mathbf{F}$, and $\mathbf{R}$. Marginal posterior distributions of all unknowns were estimated using the Gibbs sampling algorithm. The TM program (http://snp.toulouse.inra.fr/ alegarra) was used for all Gibbs sampling procedures. The lengths of the chain and the burn-in period were assessed by visual inspection of trace plots, and by the diagnostic tests described by Geweke (1992) and Gelman and Rubin (1992). After some preliminary analysis, chains of 850,000 samples were used, with a burn-in period of 50,000 . Subsequently, 1 in every 200 successive samples was retained. The mean was used as point estimate of parameters of concern. For the phenotypic, genetic, farm, and residual correlations, besides the mean of each marginal posterior distribution, we also estimated the probability of each mean being greater than 0 when the mean is positive, or lower than 0 when the mean is negative $(\mathrm{P})$. We considered all estimates with $\mathrm{P}$ greater than $90 \%$ as "relevant" correlations. A more detailed description of these features can be found in Blasco (2005).

Intra-farm heritability $\left(h^{2}\right)$ was computed as

$$
h^{2}=\frac{4 \sigma_{\mathrm{s}}^{2}}{\sigma_{\mathrm{s}}^{2}+\sigma_{\mathrm{e}}^{2}},
$$

where $\sigma_{\mathrm{s}}^{2}$ and $\sigma_{\mathrm{e}}^{2}$ are sire and residual variances, respectively.

The proportion of the total variance caused by farmdate $\left(h_{f}\right)$ was computed as

$$
h_{f}=\frac{\sigma_{\mathrm{f}}^{2}}{\sigma_{\mathrm{s}}^{2}+\sigma_{\mathrm{f}}^{2}+\sigma_{\mathrm{e}}^{2}} .
$$

Here, $\sigma_{\mathrm{s}}^{2}, \sigma_{\mathrm{f}}^{2}$, and $\sigma_{\mathrm{e}}^{2}$ were additive sire, farm-date, and residual variances, respectively.

The additive genetic correlations $\left(r_{a}\right)$ were computed as

$$
r_{a}=\frac{\sigma_{\mathrm{s} 1 \mathrm{~s} 2}}{\sigma_{\mathrm{s} 1} \cdot \sigma_{\mathrm{s} 2}}
$$

where $\sigma_{\mathrm{s} 1, \mathrm{~s} 2}$ was the sire additive sire covariance between traits 1 and 2 ; and $\sigma_{\mathrm{s} 1}$ and $\sigma_{\mathrm{s} 2}$ were the sire genetic standard deviations for traits 1 and 2, respectively.

The phenotypic correlations $\left(r_{p}\right)$ were computed as

$$
r_{p}=\frac{\sigma_{\mathrm{p} 1, \mathrm{p} 2}}{\sigma_{\mathrm{p} 1} \cdot \sigma_{\mathrm{p} 2}},
$$

where $\sigma_{\mathrm{p} 1, \mathrm{p} 2}$ was the phenotypic covariance between traits 1 and 2 ; and $\sigma_{\mathrm{p} 1}$ and $\sigma_{\mathrm{p} 2}$ were the phenotypic standard deviations for traits 1 and 2, respectively. The phenotypic variance and covariance were computed by summing the 3 random effects (co)variance components.

The farm-date correlations $\left(r_{f}\right)$ were computed as

$$
r_{f}=\frac{\sigma_{\mathrm{f} 1, \mathrm{f} 2}}{\sigma_{\mathrm{f} 1} \cdot \sigma_{\mathrm{f} 2}},
$$

where $\sigma_{\mathrm{f} 1, \mathrm{f} 2}$ was the farm-date covariance between traits 1 and 2 , and $\sigma_{\mathrm{f} 1}$ and $\sigma_{\mathrm{f} 2}$ were the farm-date standard deviations for traits 1 and 2 , respectively.

The residual correlations $\left(r_{e}\right)$ were computed as

$$
r_{e}=\frac{\sigma_{\mathrm{e} 1, \mathrm{e} 2}}{\sigma_{\mathrm{e} 1} \cdot \sigma_{\mathrm{e} 2}},
$$

where $\sigma_{\mathrm{e} 1, \mathrm{e} 2}$ was the residual covariance between traits 1 and 2 , and $\sigma_{\mathrm{e} 1}$ and $\sigma_{\mathrm{e} 2}$ were the residual standard deviations for traits 1 and 2 , respectively.

\section{RESULTS AND DISCUSSION}

\section{Descriptive Statistics and Source of Variation of Milk Quality and Technological Properties}

Table 1 summarizes the descriptive statistics of milk yield, composition, and coagulation traits, and the results from the linear model [1]. The effects of flock size, individual farm within flock size, stage of lactation, parity, daily milk yield, and the MUCM (individual pendulum of the Formagraph instrument) on milk traits are reported and discussed in 2 previous papers using data sets interrelated to the one of the present study (Pazzola et al., 2014; Vacca et al., 2015).

The average value of daily milk yield was in agreement with recent papers on the same sheep breed (Sitzia et al., 2015; Puledda et al., 2017) but higher 
PAZZOLA ET AL.

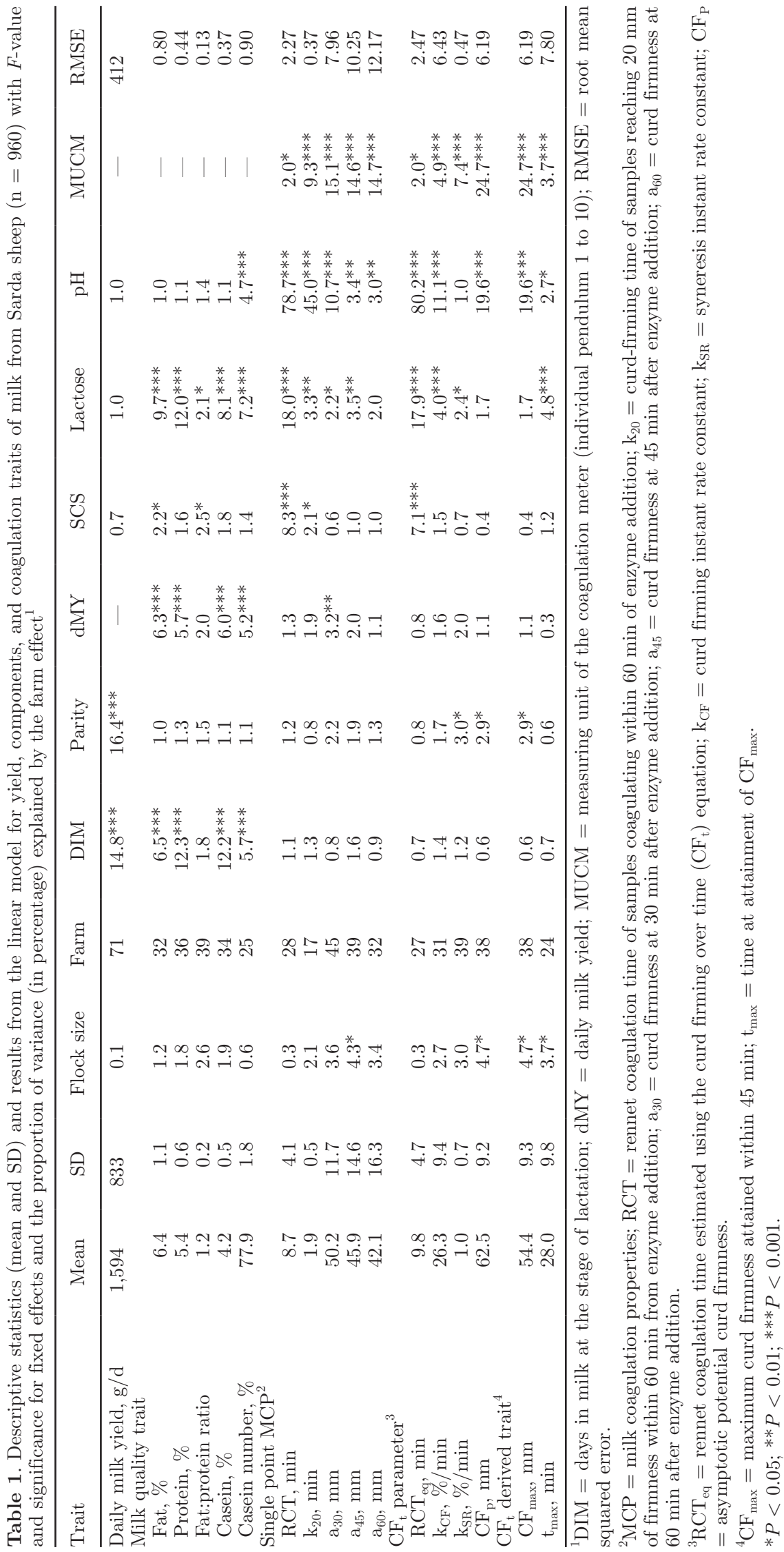


than those published in older ones (Macciotta et al., 1999; Pulina et al., 2005). This result may be indicative of a fast increasing of milk yield in the Sarda sheep throughout the last decades, which is a general feature of genetic schemes in dairy sheep breeds (Carta et al., 2009). On the other hand, the negative effects of a fast increasing of milk yield are well known in dairy farming. The increase in milk yield per cow has been proven as one of the causes for increased incidence of mastitis and reproductive disorders, because of the unfavorable genetic correlation between those traits (Koeck et al., 2014). Fat, protein, casein, lactose concentration, and $\mathrm{pH}$ were in line with data recorded in previous studies on sheep milk (Ramos and Juarez, 2011), and specifically, on the Sarda breed (Pulina et al., 2005; Manca et al., 2016).

In the present study, we decided to include simultaneously all the 3 mastitis indicators in the analysis model to assess the effect of each single trait (SCS, lactose, and $\mathrm{pH})$ corrected (independently) for the other indicators. In a preliminary model, we also tested these indicators one at a time with the other fixed effects (DIM, parity, MUCM, dMY, and flock size; data not reported in the study). Results obtained with the 2 different models (indicators included together in the model vs. each indicator at a time) were similar in terms of the significance of SCS, lactose, and pH effects ( $F$-values and significance slightly lower when tested together), and the least squares means patterns of coagulation traits were absolutely similar. Given that each of 3 indicator were correlated with each other, it was not unexpected that in the preliminary model with one trait at a time, the significance level for each one was greater than in the final combined analysis.

\section{Effect of SCS on Milk Quality and Technological Properties}

Values of SCC of the data set (mean values and SD $1,251 \pm 2,991 \times 1,000$ cells $/ \mathrm{mL}$, data not shown in tables) were characterized by a very large range of variation (Pazzola et al., 2014). In agreement with the review by Riggio and Portolano (2015), a value of $\mathrm{SCC}$ up to one million per $\mathrm{mL}$ is a normal finding in milk from healthy ewes. In particular, 291 out of 1,114 samples of our study, $26 \%$, were higher than the limit of $750,000 / \mathrm{mL}$ reported in the US PMO (2007). Mean values and standard deviation of the logarithmic value, SCS, was $4.71 \pm 2,13$, data not shown in tables.

The effect of SCS was significant for some of the measured traits, and specifically for fat content and fat: protein ratio at $P<0.05$, as well as for $\mathrm{RCT}$ and $\mathrm{RCT}_{\mathrm{eq}}$ at $P<0.001$ (Table 1). According to SCS classes, the values for fat content and fat:protein ratio followed a nonlinear quadratic trend (Supplemental Table S1; https://doi.org/10.3168/jds.2017-13975). This finding is not in agreement with other studies on dairy species, but the diversity of the protocols used, SCC levels, and statistics should be noted. Albenzio et al. (2004), in Comisana ewes, and Bobbo et al. (2016), in dairy cows, find that the most significant effect of SCC is on protein and lactose content, but not on fat content. Those authors also report a general inconsistency of results among the studies dealing with the effect of SCC on milk composition, and speculate that the inflammatory process associated with the high levels of SCC could affect the mammary cells during biosynthesis of both protein and fat fractions.

Among the coagulation single point traditional MCP and CF traits, the effect of SCS significantly affected RCT and $\mathrm{RCT}_{\text {eq }}$ (Table 1), but not $\mathrm{a}_{30}, \mathrm{a}_{45}$, and $\mathrm{a}_{60}$. This is in accordance with the finding that curd firmness in the sheep species is almost independent of coagulation time (Pazzola et al., 2014). Despite the significant curvilinear pattern (quadratic contrast) for RCT and $\mathrm{RCT}_{\text {eq }}$ (Supplemental Table S1; https://doi .org/10.3168/jds.2017-13975), the highest mean values were recorded for milk samples with SCS higher than 7.37. The delayed milk coagulation is in agreement with previous studies. With regard to dairy cows, Bobbo et al. (2016) have recently shown that SCC have a nonlinear effect on milk technological traits. With regard to sheep, Albenzio et al. (2004), in an investigation focused on single point MCP up to $30 \mathrm{~min}$, reported a more evident increase of coagulation time with high SCC, especially in the final stages of lactation. Also, Rovai et al. (2015) reported that RCT of sheep milk is even doubled for infected vs. uninfected udder. In addition, the study by Vacca et al. (2015) showed that milk samples classified as not coagulated, on the basis of curd-firming modeling, are characterized by the highest value of SCS, which is about 2 -fold compared with coagulated samples. The influence of SCC on rennet coagulation times and the $\mathrm{CF}_{\mathrm{t}}$ models' parameters are shown in Figure 1a. This summarizes that when SCC was very high (>7.37 SCS), the time after rennet addition to gelification was delayed. On the other hand, the slightly higher $\mathrm{CF}_{\mathrm{t}}$ values shown after the reaching of the maximum value of curd firmness $\left(\mathrm{CF}_{\max }\right)$ of the samples belonging to the lowest SCS class $(<2.07)$ were not significantly different from the other classes. The effect of SCC on milk coagulation, also in animals without clinical signs of mastitis, is attributable to the proteolytic effect of some enzymes [e.g., plasmin, responsible for the augmented degradation of caseins (Poulsen et al., 2015)]. 
(a) SCS

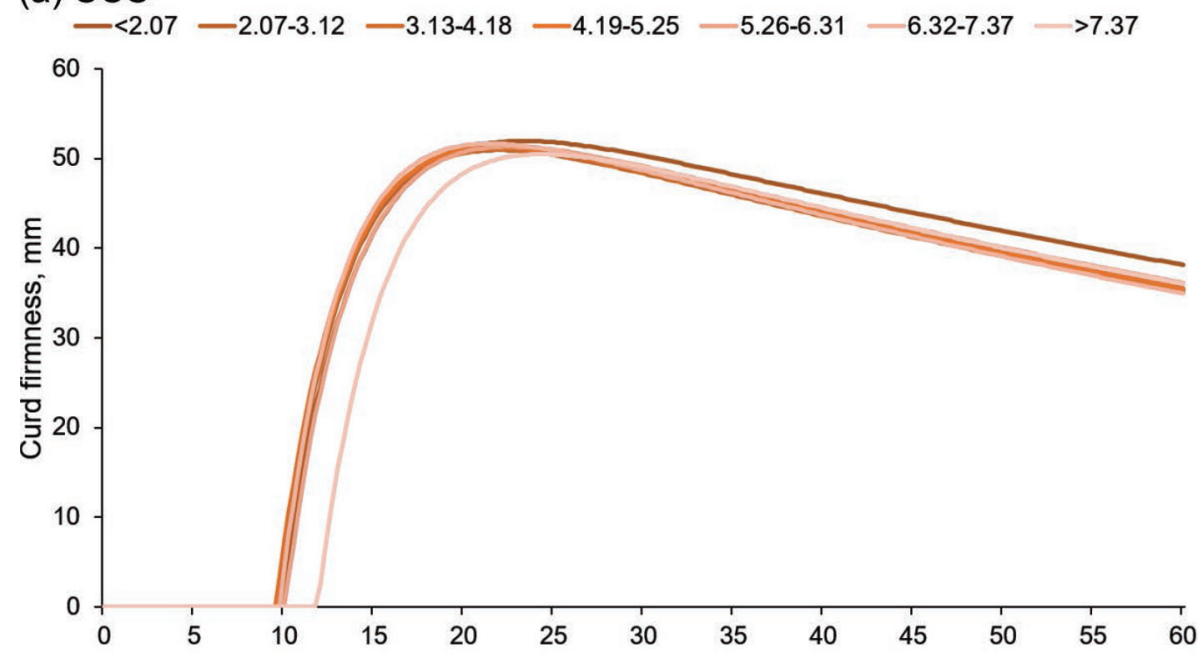

(b) Lactose

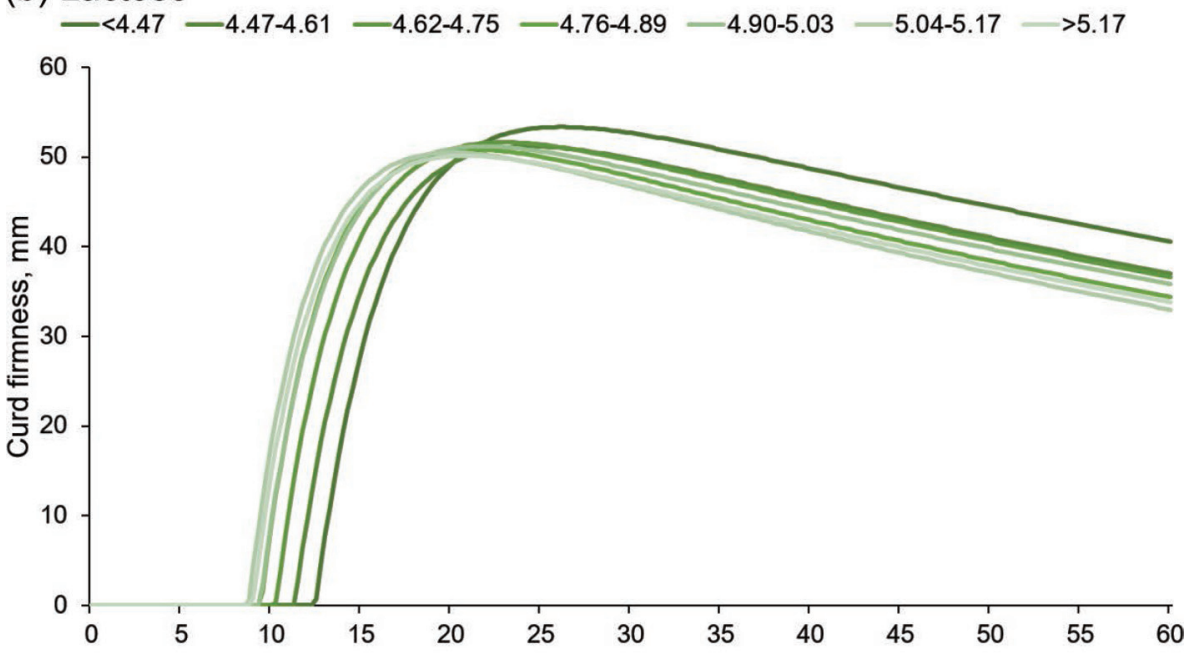

(c) $\mathrm{pH}$

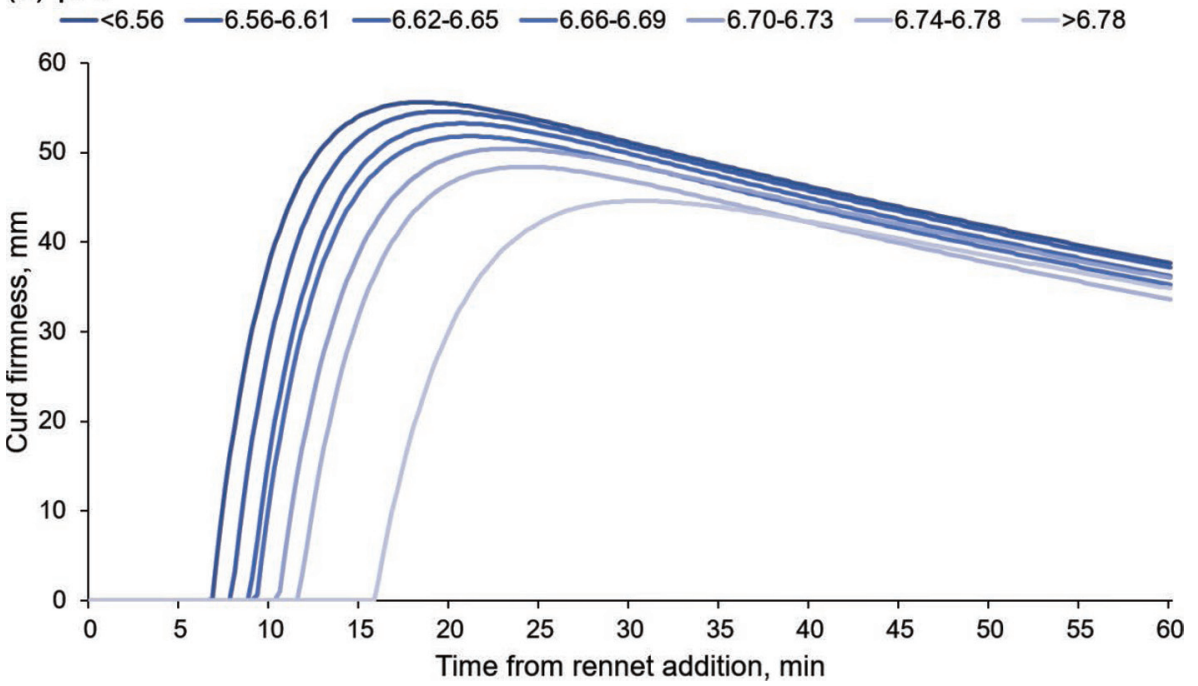

Figure 1. Pattern of curd firmness after rennet addition [curd firming over time $\left(\mathrm{CF}_{\mathrm{t}}\right)$ modeling] of milk samples according to SCS (a), lactose concentration (b), and $\mathrm{pH}(\mathrm{c})$ effects. Color version available online. 


\section{Effect of Lactose on Milk Quality and Technological Properties}

Mean values and standard deviation for lactose were $4.81 \pm 0.28 \mathrm{~g} / 100 \mathrm{~mL}$ (data not shown in tables). Lactose concentration was significant for almost all the measured milk traits, with high values of significance (Table 1). In particular, fat, protein, and casein content, and fat:protein ratio were characterized by a linear decrease with increasing percentage of lactose classes, whereas casein number was the opposite. Coagulation times and CF were shorter up to about $20 \%$ from the lowest to the highest class of lactose content: RCT from 11.4 to 8.2, $\mathrm{RCT}_{\text {eq }}$ from 12.5 to 9.0 and $\mathrm{k}_{20}$ from 2.08 to $1.94 \mathrm{~min}$. Classes of lactose higher than $4.76 \%$ were characterized by a general linear decrease of curd firmness values, specifically $\mathrm{a}_{30}$ and $\mathrm{a}_{45}$. Analysis of modeling of curd firmness summarized all these findings. Indeed, contrasts revealed a linear trend with the lowest lactose classes characterized by the decrease of $\mathrm{k}_{\mathrm{CF}}$ and $\mathrm{k}_{\mathrm{SR}}$ and the increase of $\mathrm{CF}_{\mathrm{p}}, \mathrm{CF}_{\max }$ and $\mathrm{t}_{\max }$ (Supplemental Table S2; https://doi.org/10.3168/jds .2017-13975). These results led to the generalized delay of coagulation, the increase of the maximum $\mathrm{CF}$, and the slowdown of syneresis processes for the samples belonging to the lowest classes of lactose, as clearly shown in Figure 1b. The valid mechanisms to explain the association between lactose and MCP is still to be clarified (Poulsen et al., 2015). In accordance with the role of lactose as an osmotic regulator in milk demonstrated by those last authors, and the negative association between lactose and protein in our study (the lower the lactose, the higher the protein content; Table 3), we can speculate that the real mechanism was fairly linked to the modification of percentage and composition of minerals and proteins.

Results of the present study showed that lactose concentration lower than $4.61 \%$ should be considered as an alarm because of the deterioration of technological traits of milk gelification and are consistent with other authors who consider the reduction of lactose content as a potential indicator of subclinical mastitis. Bianchi et al. (2004), in research performed on Sarda ewes, recorded a decrease of lactose from 4.80 to $4.51 \mathrm{~g} / 100 \mathrm{~mL}$ in healthy versus infected udder. Also, Vivar-Quintana et al. (2006) detected that in Spanish sheep the concentration of lactose is significantly lower with the increase of SCC. Manca et al. (2016) have recently demonstrated a marked negative correlation between lactose and SCS. Many authors have tried to explain the uniformity of results throughout the different papers and the reliability of lactose as a marker for udder health. Munro et al. (1984), and more recently, Vivar-Quintana et al. (2006), speculated that mammary epithelial cell damage due to the inflammatory process can reflect on the lactose content and that a decreased blood flow to the udder can reduce the availability of glucose for the synthesis of lactose. Albenzio et al. (2004) suggested that the lower content of lactose in milk samples with high SCC is attributable to a partial replacement of lactose with other osmotically active components such as the chlorides.

\section{Effect of $\mathrm{pH}$ on Milk Quality and Technological Properties}

Mean values and standard deviation for $\mathrm{pH}$ were $6.67 \pm 0.09$ (data not shown in tables). The $\mathrm{pH}$ had a high significant effect almost exclusively on coagulation traits, except $\mathrm{k}_{\mathrm{SR}}$ (Table 1). All significant trends were of the linear type. Starting from the first $\mathrm{pH}$ class (milk samples with $\mathrm{pH}$ lower than 6.56) to the last (higher than 6.78), the increase of single point RCT (from 6 to $14.3 \mathrm{~min}$ ), $\mathrm{k}_{20}$ (from 1.65 to $2.65 \mathrm{~min}$ ), and the decrease of the 3 curd firmness $\mathrm{a}_{30}, \mathrm{a}_{45}$, and $\mathrm{a}_{60}$ were recorded (Supplemental Table S3; https://doi.org/10.3168/jds .2017-13975). Analysis of the models' parameters also revealed the concurrent increase of the estimated $\mathrm{RCT}_{\mathrm{eq}}$ and $\mathrm{t}_{\max }$, and the decrease of $\mathrm{k}_{\mathrm{CF}}, \mathrm{CF}_{\mathrm{p}}$, and $\mathrm{CF}_{\max }$ (Supplemental Table S3), with an intense worsening of the arched line summarizing coagulation and syneresis process, mainly for the samples with $\mathrm{pH}$ higher than 6.78 (Figure 1c).

Among the milk traits, $\mathrm{pH}$ is often indicated as a marker of udder inflammation for both cattle (Kelly et al., 2011) and sheep species (Albenzio et al., 2004). The results reported in the present study are in agreement with previous data available in the literature. The $\mathrm{pH}$ is one of the most important parameters influencing the stability of casein micelles and thus the milk coagulation (Bencini, 2002; Pirisi et al., 2007). Milk samples with $\mathrm{pH}$ tending to basicity are characterized by longer clotting times. Bittante et al. (2017), analyzing the phenotypic correlation among the milk traits of a data set related to the one of the present study, recently highlighted a negative effect of high $\mathrm{pH}$ on coagulation traits, especially coagulation times, but not curd syneresis.

\section{Heritability of SCS, Lactose, and $\mathrm{pH}$ and Correlations with Milk Quality and Technological Properties}

The heritability estimates of ovine milk SCS, lactose, and $\mathrm{pH}$ according to a Bayesian approach is shown in Table 2. A marked uncertainty was demonstrated for all 3 parameters. The mean value of intra-farm heritability estimates for SCS was 0.173. The first estimates found in literature are usually much lower. The value 
Table 2. Estimates of sire variance $\left(\sigma_{\mathrm{s}}^{2}\right)$ farm-date variance $\left(\sigma_{\mathrm{f}}^{2}\right)$ residual variance $\left(\sigma_{\mathrm{e}}^{2}\right)$ intra-farm heritability, and farm-date variance as proportions of total variance $\left(h_{f}\right)$ for SCS, lactose, and $\mathrm{pH}^{1}$

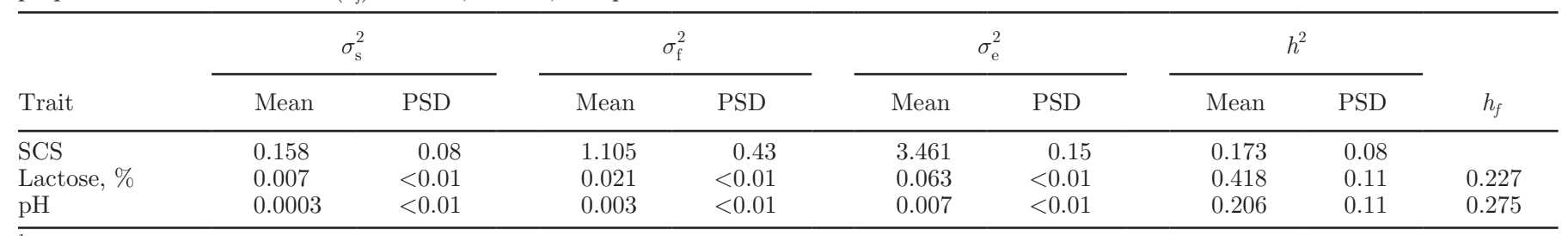

${ }^{1}$ Mean $=$ mean of the marginal posterior density of the parameter; PSD = posterior standard deviation.

for Spanish Churra ewes is 0.04 (Baro et al., 1994), but as reviewed by Carta et al. (2009) on various breeds, the large majority of estimates ranges in the interval between 0.10 and 0.20. de la Fuente et al. (2011) found a heritability for SCS at 0.09 in primiparous and 0.13 in multiparous Churra ewes. Also, Riggio et al. (2010), on Valle del Belice sheep, estimated a heritability value at 0.09 . The same authors found that the heritability value of SCS was only 0.03 in ewes with positive milk bacterial count and 0.10 for ewes with negative bacterial count, with the genetic correlation between the 2 traits being 0.62. Also, Puledda et al. (2017), on the Sarda breed, reported very low values of heritability, particularly for SCS at 0.03 .

The phenotypic, genetic, farm, and residual correlations between SCS and the other milk yield, quality, and technological traits are summarized in Table 3. Correlations of SCS with milk yield were low $(-0.259$ to +0.130$)$ as were correlations with fat and protein content $(+0.058$ to +0.335$)$, which were positive and consequently unfavorable.

The information in the literature on genetic correlations between SCS and other milk traits is not exhaustive. el-Saied et al. (1998) showed small phenotypic and genetic correlations between SCS and milk yield and protein content. As reviewed by Carta et al. (2009), phenotypic and genetic relationships between SCS and milk yield and composition are generally low and not consistent among different studies.

In our study, SCS was much more positively (unfavorably) correlated with $\mathrm{RCT}$ and $\mathrm{RCT}_{\text {eq }}$ with estimates between +0.449 (farm correlation between SCS and $\mathrm{RCT}$ ) and +0.616 (genetic correlation between SCS and RCT). Correlations between SCS and the other traditional MCP were much lower, with the remarkable exception of the genetic unfavorable correlations with $\mathrm{k}_{20}(+0.588)$ and $\mathrm{a}_{30}(-0.468)$. Also, for $\mathrm{CF}_{\mathrm{t}}$ equation parameters and derived traits, the correlations with SCS were generally low, with the remarkable exception of the positive $(+0.521)$ genetic correlation with the time required to achieve the maximum curd firmness $\left(t_{\max }\right)$. Puledda et al. (2017), on the same sheep breed, obtained similar results for SCS phenotypic correlations with $\mathrm{RCT}$ and $\mathrm{k}_{20}$, whereas genetic correlations were very different, being very small and negative $(-0.14$ between SCS and RCT) and very large and negative $\left(-0.72\right.$ between SCS and $k_{20}$ ).

With regard to the other 2 traits, the mean value of intra-farm heritability of lactose content and $\mathrm{pH}$ of ovine milk were 0.418 and 0.206 , respectively (Table 2 ). Due to the limited data available in the literature, the only comparison could be done with the value of 0.16 recorded for $\mathrm{pH}$ by Puledda et al. (2017) on the same breed, which is similar to our estimate.

The phenotypic, genetic, farm, and residual correlations between lactose and $\mathrm{pH}$, and the other milk traits are reported in Table 3. Similarly to the results evidenced for SCS, correlations with milk yield were generally moderate $(-0.277$ to +0.247$)$ with the exception of the larger correlation between lactose content and milk yield at the farm level $(+0.430)$. Lactose showed negative correlations with fat, protein, and casein contents of milk $(-0.082$ to -0.475$)$, whereas $\mathrm{pH}$ was not correlated with milk composition, except for the positive genetic correlation with protein and casein. Also, lactose (favorably) and $\mathrm{pH}$ (unfavorably) were much more correlated at the phenotypic, genetic, farm, and residual levels, with $\mathrm{RCT}, \mathrm{RCT}_{\mathrm{eq}}, \mathrm{k}_{20}$, and $\mathrm{t}_{\max }$ (only genetically for $\mathrm{pH}$ ), and less with the other $\mathrm{CF}$ traits.

Analysis performed on the effects of SCS, lactose, and $\mathrm{pH}$ clearly evidenced that these 3 milk traits showed very high values of correlation with each other's (negatively for lactose with SCS and lactose with $\mathrm{pH}$, positively for SCS with pH; Table 3). Multivariate factors analyses of milk traits have been carried out in different dairy species, and in all of the cases an udder health latent explanatory variable was proposed. In the bovine species, Macciotta et al. (2012) reported an udder health factor (which is the fourth explanatory factor of that data set, explaining $10 \%$ of total variance), mainly based on lactose (coefficient +0.818 ) and SCS $(-0.651)$, but not on milk pH. In the Sarda goat, Vacca et al. (2016) found a hygiene factor (second, 19\% of total variance) based on SCS $(-0.83)$, lactose $(+0.71)$, and also $\log$ bacterial count $(-0.70)$, but not on milk $\mathrm{pH}$. In the Girgentana goat, Todaro et al. (2005) reported that a 
INDICATORS OF SUBCLINICAL MASTITIS IN SHEEP MILK

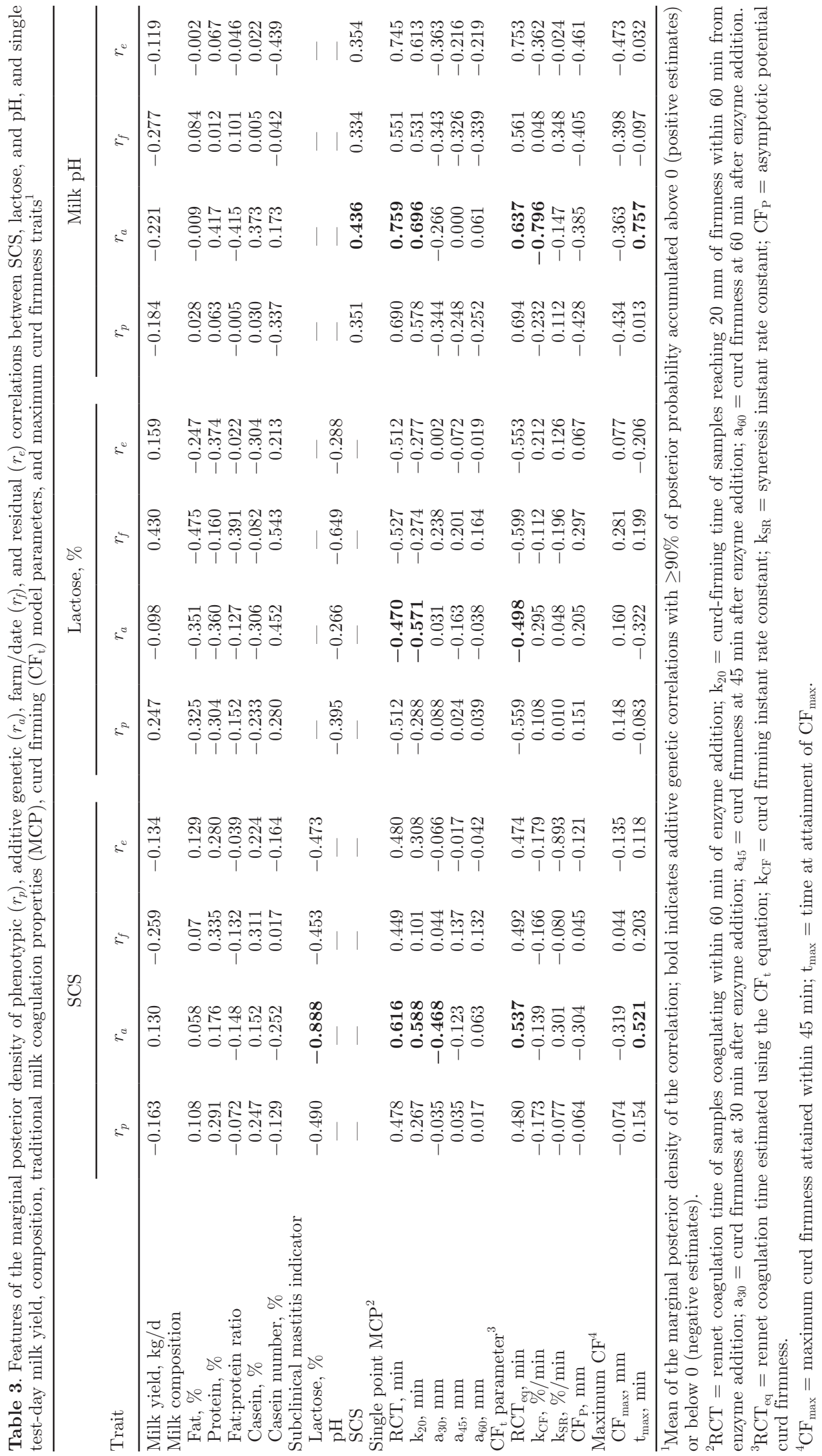


factor called slow milks (first, $51 \%$ of total variance) is associated with milk pH $(+0.852)$ and RCT $(+0.562)$. Manca et al. (2016) proposed, for the Sarda sheep, an udder health factor (second, $19 \%$ of total variance) that is mainly based on lactose content $(+0.87)$, milk $\mathrm{NaCl}$ $(-0.86)$, milk freezing point $(+0.64)$, and SCS $(-0.42)$, but not $\mathrm{pH}$. In that last study, both milk freezing point and $\mathrm{NaCl}$ content were highly correlated with lactose content. It worth noting that those authors obtained a very high value of heritability estimate of this latent explanatory variable (0.378), similar to our heritability estimate of lactose.

\section{CONCLUSIONS}

Evidence of phenotypic and genetic relationships between predictive markers of udder health and milk traits is limited for the sheep species. In the present study, from a phenotypic point of view, the effect of SCS, lactose, and $\mathrm{pH}$ were significant on many of the milk traits. High levels of somatic cells caused a general delay, and consequently, the worsening of milk coagulation. Similar effects were recorded for lactose concentration and $\mathrm{pH}$, which caused a linear decrease of curd firmness values and a predicted decreasing quality of milk processing. The heritability estimates showed very high values for SCS, whereas for lactose and $\mathrm{pH}$ we recorded median values in line with data available in the literature. The SCS and lactose, and to a lesser extent $\mathrm{pH}$, were closely related among each other, especially from the genetic point of view, and all together draw a picture of udder health that has a strong relationship with milk technological traits. Therefore, these traits could be used as indicators to prevent mastitis and improve cheese-making ability of ovine milk at both the management and genetic levels.

\section{ACKNOWLEDGMENTS}

This research was supported by a grant from the Fondazione di Sardegna (Sardinia Foundation). The authors thank the farmers for giving access to their farms, the AIPA/APA (Provincial Farmers Associations) of Cagliari, Nuoro, Sassari, and Oristano for their support in sample collection and ARA Sardegna (Regional Farmer Association of Sardinia) for support in milk analysis.

\section{REFERENCES}

Albenzio, M., M. Caroprese, A. Santillo, R. Marino, and A. Sevi. 2004. Effects of somatic cell count and stage of lactation on the plasmin activity and cheese-making properties of ewe milk. J. Dairy Sci. $87: 533-542$.
Ali, A. K. A., and G. E. Shook. 1980. An optimum transformation for somatic cell concentration in milk. J. Dairy Sci. 63:487-490.

Auldist, M., S. Coats, G. Rogers, and G. McDowell. 1995. Changes in the composition of milk from healthy and mastitic dairy cows during the lactation cycle. Anim. Prod. Sci. 35:427-436.

Baro, J. A., J. A. Carriedo, and F. San Primitivo. 1994. Genetic parameters of test day measures for somatic cell count, milk yield, and protein percentage of milking ewes. J. Dairy Sci. 77:2658-2662.

Bencini, R. 2002. Factors affecting the clotting properties of sheep milk. J. Sci. Food Agric. 82:705-719.

Berthelot, X., G. Lagriffoul, D. Concordet, F. Barillet, and D. Bergonier. 2006. Physiological and pathological thresholds of somatic cell counts in ewe milk. Small Rumin. Res. 62:27-31.

Bianchi, L., A. Bolla, E. Budelli, A. Caroli, C. Casoli, M. Pauselli, and E. Duranti. 2004. Effect of udder health status and lactation phase on the characteristics of Sardinian ewe milk. J. Dairy Sci. 87:2401-2408.

Bittante, G., C. Cipolat-Gotet, M. Pazzola, M. L. Dettori, G. M. Vacca, and A. Cecchinato. 2017. Genetic analysis of coagulation properties, curd firming modeling, milk yield, composition and acidity in Sarda dairy sheep. J. Dairy Sci. 100:385-394.

Bittante, G., M. Penasa, and A. Cecchinato. 2012. Invited review: Genetics and modeling of milk coagulation properties. J. Dairy Sci. 95:6843-6870.

Blasco, A. 2005. The use of Bayesian statistics in meat quality analyses: A review. Meat Sci. 69:115-122. https://doi.org/10.1016/j .meatsci.2004.06.012.

Bobbo, T., C. Cipolat-Gotet, G. Bittante, and A. Cecchinato. 2016. The nonlinear effect of somatic cell count on milk composition, coagulation properties, curd firmness modeling, cheese yield, and curd nutrient recovery. J. Dairy Sci. 99:5104-5119.

Boyazoglu, J., and P. Morand-Fehr. 2001. Mediterranean dairy sheep and goat products and their quality. A critical review. Small Rumin. Res. 40:1-11.

Carta, A., S. Casu, and S. Salaris. 2009. Invited review: Current state of genetic improvement in dairy sheep. J. Dairy Sci. 92:5814-5833.

de la Fuente, L. F., C. Gonzalo, J. P. Sánchez, R. Rodríguez, J. A. Carriedo, and F. San Primitivo. 2011. Genetic parameters of the linear body conformation traits and genetic correlations with udder traits, milk yield and composition, and somatic cell count in dairy ewes. Can. J. Anim. Sci. 91:585-591.

el-Saied,, U. M., J. A. Carriedo, and F. San Primitivo. 1998. Heritability of test day somatic cell counts and its relationship with milk yield and protein percentage in dairy ewes. J. Dairy Sci. 81:29562961.

EU. 2004. Regulation (EC) no 853/2004 of the European Parliament and of the Council of 29 April 2004 laying down specific hygiene rules for on the hygiene of foodstuffs. Off. J. Eur. Union L 226:2282.

Gelman, A., and D. B. Rubin. 1992. Inference from iterative simulation using multiple sequences. Stat. Sci. 7:457-511.

Geweke, J. 1992. Evaluating the accuracy of sampling-based approaches to the calculation of posterior moments (with discussion). Pages 164-193 in Bayesian Statistics. J. O. Berger, J. M. Bernardo, A. P. Dawid, and A. F. M. Smith, ed. Oxford University Press, Oxford, UK.

Gonçalves, J. L., T. Tomazi, J. Regina Barreiro, D. C. Beuron, M. A. Arcari, S. H. I. Lee, C. M. de Magalhães Rodrigues Martins, J. Pessoa Araújo Junior, and M. Veiga dos Santos. 2016. Effects of bovine subclinical mastitis caused by Corynebacterium spp. on somatic cell count, milk yield and composition by comparing contralateral quarters. Vet. J. 209:87-92.

Hogeveen, H. 2011. Mastitis therapy and control. Automated online detection of abnormal milk. Pages $422-428$ in Encyclopedia of Dairy Sciences. 2nd ed. J. W. Fuquay, P. F. Fox, and P. L. H. McSweeney, ed. Academic Press, San Diego, CA.

Jensen, D. B., H. Hogeveen, and A. D. de Vries. 2016. Bayesian integration of sensor information and a multivariate dynamic linear model for prediction of dairy cow mastitis. J. Dairy Sci. 99:73447361 . 
Kelly, A. L., G. Leitner, and U. Merin. 2011. Milk quality and udder health. Test methods and standards. Pages 894-901 in Encyclopedia of Dairy Sciences. 2nd ed. J. W. Fuquay, P. F. Fox, and P. L. H. McSweeney, ed. Academic Press, San Diego, CA.

Koeck, A., S. Loker, F. Miglior, D. F. Kelton, J. Jamrozik, and F. S. Schenkel. 2014. Genetic relationships of clinical mastitis, cystic ovaries, and lameness with milk yield and somatic cell score in first-lactation Canadian Holsteins. J. Dairy Sci. 97:5806-5813.

Leitner, G., Y. Lavon, Z. Matzrafi, O. Benun, and D. Bezman. 2016. Somatic cell counts, chemical composition and coagulation properties of goat and sheep bulk tank milk. Int. Dairy J. 58:9-13.

Macciotta, N. P. P., A. Cappio-Borlino, and G. Pulina. 1999. Analysis of environmental effects on test day milk yields of Sarda dairy ewes. J. Dairy Sci. 82:2212-2217.

Macciotta, N. P. P., A. Cecchinato, M. Mele, and G. Bittante. 2012. Use of multivariate factor analysis to define new indicator variables for milk composition and coagulation properties in Brown Swiss cows. J. Dairy Sci. 95:7346-7354.

Manca, M. G., J. Serdino, G. Gaspa, P. Urgeghe, I. Ibba, M. Contu, P. Fresi, and N. P. P. Macciotta. 2016. Derivation of multivariate indices of milk composition, coagulation properties, and individual cheese yield in dairy sheep. J. Dairy Sci. 99:4547-4557.

Munro, G. L., P. A. Grieve, and B. J. Kitchen. 1984. Effects of mastitis on milk yield, milk composition, processing properties and yield and quality of milk products. Aust. J. Dairy Technol. 39:7-16.

Othmane, M. H., L. F. de la Fuente Crespo, J. A. Carriedo, and F. San Primitivo. 2002. Heritability and genetic correlations of test day milk yield and composition, individual laboratory cheese yield and somatic cell count for dairy ewes. J. Dairy Sci. 85:2692-2698.

Pazzola, M., M. L. Dettori, C. Cipolat-Gotet, A. Cecchinato, G. Bittante, and G. M. Vacca. 2014. Phenotypic factors affecting coagulation properties of milk from Sarda ewes. J. Dairy Sci. 97:72477257.

Pirisi, A., A. Lauret, and J. P. Dubeuf. 2007. Basic and incentive payments for goat and sheep milk in relation to quality. Small Rumin. Res. 68:167-178.

Poulsen, N. A., A. J. Buitenhuis, and L. B. Larsen. 2015. Phenotypic and genetic associations of milk traits with milk coagulation properties. J. Dairy Sci. 98:2079-2087.

Puledda, A., G. Gaspa, M. G. Manca, J. Serdino, P. P. Urgeghe, C Dimauro, R. Negrini, and N. P. P. Macciotta. 2017. Estimates of heritability and genetic correlations for milk coagulation properties and individual laboratory cheese yield in Sarda ewes. Animal 11:920-928

Pulina, G., N. Macciotta, and A. Nudda. 2005. Milk composition and feeding in the Italian dairy sheep. Ital. J. Anim. Sci. 4:5-14.

Ramos, M., and M. Juarez. 2011. Sheep Milk. Pages 494-502 in Encyclopedia of Dairy Sciences. 2nd ed. J. W. Fuquay, P. F. Fox, and P. L. H. McSweeney, ed. Academic Press, San Diego, CA.
Riggio, V., and B. Portolano. 2015. Genetic selection for reduced somatic cell counts in sheep milk: A review. Small Rumin. Res. 126:33-42.

Riggio, V., B. Portolano, H. Bovenhuis, and S. C. Bishop. 2010. Genetic parameters for somatic cell score according to udder infection status in Valle del Belice dairy sheep and impact of imperfect diagnosis of infection. Genet. Sel. Evol. 42:30.

Rovai, M., N. Rusek, G. Caja, J. Saldo, and G. Leitner. 2015. Effect of subclinical intramammary infection on milk quality in dairy sheep: I. Fresh-soft cheese produced from milk of uninfected and infected glands and from their blends. Small Rumin. Res. 125:127-136.

Schukken, Y. H., D. J. Wilson, F. Welcome, L. Garrison-Tikofsky, and R. N. Gonzalez. 2003. Monitoring udder health and milk quality using somatic cell counts. Vet. Res. 34:579-596.

Sitzia, M., A. Bonanno, M. Todaro, A. Cannas, A. S. Atzori, A. H D. Francesconi, and M. Trabalza-Marinucci. 2015. Feeding and management techniques to favour summersheep milk and cheese production in the Mediterranean environment. Small Rumin. Res. 126:43-58.

Sorensen, D., and D. Gianola. 2002. Likelihood, Bayesian, and MCMC Methods in Quantitative Genetics. Springer-Verlag, New York, NY

Todaro, M., M. L. Scatassa, and P. Giaccone. 2005. Multivariate factor analysis of Girgentana goat milk composition. Ital. J. Anim. Sci. 4:403-410.

US PMO. 2007. Pasteurized Milk Ordinance (2007 revision) of the U.S. Food and Drug Administration. Accessed Mar. 22, 2010 https://www.fda.gov/downloads/food/guidanceregulation/ guidancedocumentsregulatoryinformation/milk/ucm513508.pdf.

Vacca, G. M., P. Paschino, M. L. Dettori, M. Bergamaschi, C. CipolatGotet, G. Bittante, and M. Pazzola. 2016. Environmental, morphological, and productive characterization of Sardinian goats and use of latent explanatory factors for population analysis. J. Anim. Sci. 94:3947-3957.

Vacca, G. M., M. Pazzola, M. L. Dettori, E. Pira, F. Malchiodi, C. Cipolat-Gotet, A. Cecchinato, and G. Bittante. 2015. Modeling of coagulation, curd firming, and syneresis of milk from Sarda ewes. J. Dairy Sci. 98:2245-2259.

Vanlandingham, A. H., E. C. Weakley Jr., E. N. Moore, and H. O. Henderson. 1941. Mastitis. I. The relationship of the development of mastitis to changes in the chlorine, lactose and casein number of milk. J. Dairy Sci. 24:383-398.

Viguier, C., S. Arora, N. Gilmartin, K. Welbeck, and R. O'Kennedy. 2009. Mastitis detection: current trends and future perspectives. Trends Biotechnol. 27:486-493.

Vivar-Quintana, A. M., E. Beneitez De La Mano, and I. Revilla. 2006. Relationship between somatic cell counts and the properties of yoghurt made from ewes' milk. Int. Dairy J. 16:262-267. 